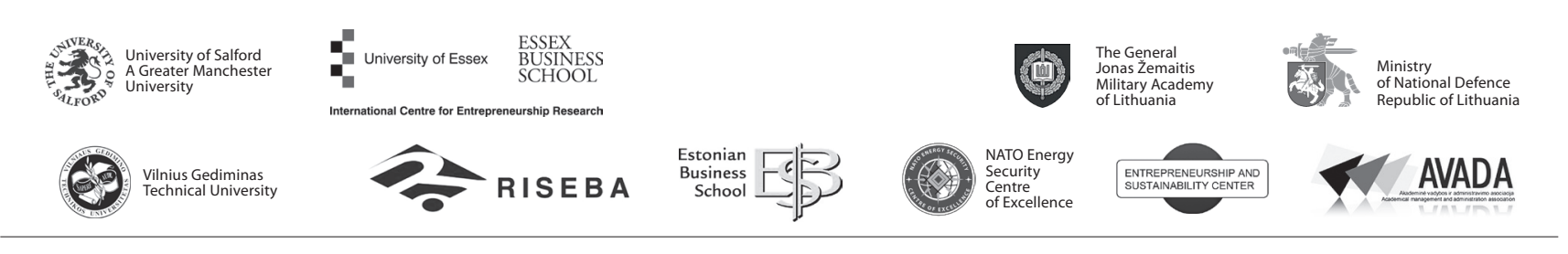

\author{
JOURNAL OF SECURITY AND SUSTAINABILITY ISSUES \\ ISSN 2029-7017 print/ISSN 2029-7025 online \\ 2017 September Volume 7 Number 1 \\ http://dx.doi.org/10.9770/jssi.2016.7.1(9)
}

\title{
THE IMPACT OF CHOSEN ECONOMIC INDICATORS ON TOURISM SUSTAINABILITY: CASE STUDY OF THE CZECH REPUBLIC AND NORWAY
}

\author{
Zuzana Jurigová ${ }^{1}$, Zuzana Tučková2 ${ }^{2}$ Oskar Solenes ${ }^{3}$ \\ 1,2 Tomas Bata University in Zlín, nám. T. G. Masaryka 5555, 760 01, Zlín, Czech Republic \\ ${ }^{2}$ Molde University College - Specialized University in Logistics, PO. Box 2110, 6402, Molde, Norway \\ E-mails:1'zjurigova@fame.utb.cz;'uckova@utb.cz; ${ }^{3}$ Oskar.Solenes@hiMolde.no
}

Received 17 November 2016; accepted 20 March 2017

\begin{abstract}
In recent years, tourism businesses have had to face rapid changes brought about by modernisation, internationalisation, social changes, and the higher demands of tourists. These features have an impact on the current level of tourism services and determine the overall economic environment on the supply and demand side. To keep up with global and national competition and these new emerging processes, it is important for managers to discover and monitor how key global figures can have an impact on the future development of tourism units in the hopes to achieve further sustainability growth. Managers should adapt to the changing environment by using new methods and strategies that make tourism units sustainable for future generations. One of the main indicators measuring economic sustainability is gross domestic product, as it captures the market value of the measured services or goods in general. For this reason, it is worthwhile to determine what the interconnections with regard to gross domestic product and tourism variable are. Through this relationship, it is possible to evaluate the health of a certain economy of tourism that can serve as a viewpoint for the management of tourism businesses in a certain state. This research looks at the relationship between the chosen indicators from the tourism sectors of the Czech Republic and Norway. Its purpose is to identify the relationship between the chosen general economic indicators measuring tourism economic prosperity, such as overall gross domestic product for international travel expenditures within a 7-year period. The main aim of the research is to determine the relationship between the chosen indicators through comparison and trend analysis. The data will be examined in order to determine the relationship between the chosen variables, as well as the strength of the dependence of both variables. Based on these findings, further research may use gross domestic product as one of the crucial indicators for the measurement of economic sustainability with respect to its added value for tourism businesses and management.
\end{abstract}

Keywords: sustainability, economy, expenditures, gross domestic product, Czech Republic, Norway, tourism

Reference to this paper should be made as follows: Jurigová, Z.; Tučková, Z; Solenes, O. 2017. The impact of chosen economic indicators on tourism sustainability: case study of the Czech Republic and Norway, Journal of Security and Sustainability Issues 7(1): 113-121. http://dx.doi.org/10.9770/jssi.2017.7.1(9)

JEL Classifications: F63, Q01, Q56, Z32

\section{Introduction}

Even from the beginnings of tourism, it is known that merchants travelled for business purposes with the aim of searching for financial security. Trade and business have been interconnected ever since. Business as a primary motive for travel has caused its spread, and nowadays trade is also an activity that promotes tourism in general. This viewpoint is based on the work of Gallega et al. (2011), who note that tourism is directly interconnected with trade. Especially in the business environment and business travels, there is much truth about the interconnection between trade causing tourism and tourism causing trade. The first option, again based on Gallega et al. (2011), resides in trade promoting tourism. It is clear that businessmen cause tourism to develop for various reasons. Firstly, business travellers not only consume goods and national products, but moreover consume services 
such as accommodation, needs to exchange currencies, or must travel in order to arrive at planned meetings. Secondly, business travellers may require the same products that they are accustomed to in their home country or vice versa. This is the export vs. import benefit, which is connected with the second option that states that tourism promotes sales. Tourists visiting a country will be consumers of national products, souvenirs, etc. and through the sale of these items, will contribute to the economic growth of the country (Gallega et al., 2011).

In recent times, tourism has played a significant role not only with regard to trade, but mostly in the overall global economy compared to other industries. Its potential causes managers of all of the related economic activities of tourism to do their best to ensure the potential of its functioning. This makes tourism a very important source of revenue for the economy. In the Czech Republic, the direct contribution of Travel and Tourism to GDP represented $2.6 \%$ of GDP in 2014 and in Norway $2.9 \%$ of total GDP in the same year, and it is forecasted to grow (WTTC, 2015a, 2015b). The primary objective of managers in the various tourism sectors is definitely to make and subsequently maximise profit and to generate business. If this is not fulfilled, any other aims become, at that point, not relevant for these managers. For this reason, tourism businesses should be aware of the need to establish a sustainable measurement system consisting of appropriate economic sustainable indicators in order to achieve this profit maximisation. By taking this step, progress can be seen, monitored, and assessed accordingly. Therefore, they should look for indicators that have an impact on the tourism sector, on their business, and require faster decisionmaking in the long term. Given the growing trend in the GDP of tourism and also the general GDP of all sectors, it is necessary to deal precisely with the potential of this variable for further decision-making.

\section{Literature review}

\section{Tourism's need for economic sustainability measurement}

From a theoretical perspective, measuring sustainability allows managers to think more strategically about their businesses because it represents "one way to introduce long-term economic prospects into our assessment of socioeconomic well-being" (Fleurbaey and Blanchet, 2013). The connection of two relatively vague terms such as sustainability and measurement could raise the question whether its interpretation and findings can be taken into real practice throughout the whole tourism industry. The importance of sustainability in tourism and its measurement is highlighted by many authors throughout the literature. Due to the fact that the term sustainability has a vague character and its objectivity has decreased due to its normative character (Moldan, 2003), its measurement is thus necessary for the possibility of its practical application. This is confirmed, for example, by Daly (1996), Bossel (1999), Vojnovic and Knezevic (2013), Rio \& Nunes (2012), and Oyola et al. (2012). In addition to these sources, governmental bodies such as the European Union (2013) and World Tourism Organisation (2004) have issued a document describing sustainability indicators and their measurement in all three pillars - namely economic, environmental, and social.

The measurement of sustainability is not an easy task even for tourism providers and managers. To quantify and measure performance in each sustainability pillar, it requires having an indicator system and knowing what each dimension is characterised and influenced by. Sustainability dimensions are described as follows:

- Economic sustainability: measures financial health and the impact of the business on stakeholders and society.

- Social sustainability: social criteria such as employment, education, health and safety, or trainings should be done in such way to benefit the business and its participants.

- Environmental: ensure that environmental issues such as energy efficiency, water, emissions, waste management, and biodiversity are consumed in a way that benefits business and protects the environment at the same time. (Brockett and Rezaee, 2012):

Many tourism units, and specifically hotel businesses, mostly focus on environmental sustainability preservation. Moreover, this "green" period serves as a good soil for its growth because it has become very popular to behave in accordance with "green" rules. Gardetti and Torres (2016) support this by saying that sustainability is nowadays "frequently reduced by associating it with environment". On the one hand, environmental sustainability can bring economic savings in terms of water, electricity, etc., but on the other hand economic sustain- 
ability should be put above social and environmental sustainability in order to make hotels and other tourism sectors such as transport, food and beverage, or tourism agencies viable. For this reason, economic performance is and should be taken as the most important of all three pillars (Gardetti and Torres, 2016).

The obvious reasons for incorporating economic sustainability into the decision-making process for managers in tourism facilities resides in its overall economic impact on the national economies. In practice, this resides in the decreased "use of resources with potentially less adverse social and environmental impacts from their use" (Dwyer, L. and Spurr, L., n.d., p.1).

\section{Gross domestic product (GDP) as a main indicator of economic measurement in tourism sustainability}

Generally, the economic sustainability indicators that are relevant for managers and monitor their financial health include "return on assets, return on equity, market value, growth, quality and quantity of earnings, research and development and market share" (Gardetti and Torres, 2016). These indicators measure concrete activity in a certain tourism facility regardless of the negative effects occurring on the economic stage in which these businesses operate. At this point, businesses are a part of the economic cycle and therefore must realise that they do not function in isolation from their economic surroundings, and must concentrate on general economic prosperity above all. Generally speaking, if tourism can lead to growth of gross domestic product, increased employment, or the exchange of currency, all of these indicators can obviously cause a boomerang effect in the form of contraction or a boom for tourism facilities - and their profits. For this reason, concentrating on indicators such as economic value added or return on equity measured within a concrete tourism facility is not enough, and businesses should be advised to concentrate on long-term economic indicators, ups and downs in the economic cycle, and periodically review the economic situation.

Focusing primarily on gross domestic product, it was one of the first measurement indicators assessing the economic health and sustainability of tourism (Daly, 1996; Lawn, 2006); however, some authors believe that it does not reflect all three pillars and therefore it should not be taken as a complex measurement method (Fleurbaey, M. and Blanchet, 2013; Bossel, 1999; Nováček, 2010; Jurigová, 2016).

Opponents to this view include Ki-Moon or Helen Clark, who believe that while looking at a sustainability and non-economic factors such as happiness or equity, GDP should not be the one and only indicator but there should be a new set of indicators or new sustainable development index that will complement GDP (United Nations Development Programme, 2012). With this in mind, sustainable development should include not only GDP as a representative of the economic dimension, but it should "integrate financial/economic analysis with environmental and socio-cultural analysis" and these three dimensions should work as an integrated framework for long-term decision-making (Hall, Gössling, Scott, 2015, p. 78).

\section{Influence of GDP on tourism development}

In general terms, GDP as a macroeconomic indicator is one of the most used indicators for describing a state's well-being. One of the first studies that described GDP as an indicator of economic growth was undertaken by Ghali (1976). As he claimed, the development of tourism is a key factor in the strategic planning of further national economic growth.

Balcilar, M., R. van Eyden, and R. Inglesi-Lotz (2014) found that in South Africa, the relationship between tourism and GDP with the usage of the Granger causality methodology is positive. More concretely, tourism receipts were taken as a positive prediction for GDP in the period between 1960 and 2011, except in the years of 1985 and 1990. On the contrary, a different approach and research in South Africa regarding economic growth and tourism using the same Granger analysis is seen in the work of O. Akinboade or L. Braimoh (2009), who see "unidirectional causality" between tourism earnings and GDP. Similarly, J. Ridderstaat, R. Croes, and P. Nijkamp (2014) believe that the relationship is reciprocal, which means that tourist arrivals also suffer in the business cycle during times of recession or downturn and that this further influences tourism results, respectively. 
A similar study provided by Li and Chuan (2012) on the relationship between economic growth, tourism receipts, and education based on Granger causality revealed a bidirectional relationship. Based on this, it is suggested that economic growth can be concretely supported in Malaysia by promoting tourism receipts and education. The analysis of Lee and Chang (2008) showed that "unidirectional causality relationships exist from tourism growth to economic development in OECD countries, but bidirectional causality relationships are found between the two variables in non OECD countries". With this in mind, the authors advise a concentration on the relationship of tourism and economic growth from a long-term perspective.

All of the previously mentioned studies should also bear in mind the differences occurring during the various phases of business cycle during the monitored period. The impacts of phases in the economic cycle such as booms, downturns, or recessions on the demand for tourism were also studied by several authors (Crouch, 1996; Gouveia and Rodrigues, 2005; Song and Li, 2008).

However, the question remains whether tourism influences GDP in such a way that the economy could profit from this relationship, or whether the economic cycle in its different phases influences tourism and its economic outputs. The reciprocity and a clear interconnection in this relationship is confirmed by Rifai, the UNWTO Secretary General who believes that "tourism has been instrumental in supporting the economic recovery of many countries" with sustainability being a core of the whole process (UNWTO, 2015). In the end it is necessary to remind that the positive effects of tourism include tourism revenues, value creation and multiplier effect, its contribution to foreign exchange earnings and other non-economic (environmental, social and cultural) effects. The negative effects of tourism are seen in its uncoordinated development, price increases, crime, etc (Jurigová, Lencsésová, 2015).

\section{Methodology}

The aim of this research is to compare and discover the changes in international expenditures in the tourism sector and to determine its percentage of overall GDP in two tourism economies - in the Czech Republic and Norway. In other terms, it should reveal whether it is essential for managers and stakeholders to include GDP in their strategic planning and whether it is essential to look over macroeconomic data while managing tourism facilities. The research is conducted in two states, the Czech Republic and Norway. Secondary data for the research were collected from OECD statistics in a 7-year period from 2008 to 2014.

The statistical research of Cárdenas-García, Sánchez-Rivero, and Pulido-Fernandéz (2015) confirmed that Norway had the highest value of the synthetic index of economic development in 1991 from all 72 ranked countries, which points to a positive relationship between tourism growth and economic development. According to this research, Norway achieved first place followed by Sweden and France, with the Czech Republic ranked in the 39th position. Therefore, Norway was taken as a comparison basis as the data of Norway were compared with the Czech Republic.

Two variables were compared, namely gross domestic product and international travel expenditures. Gross domestic product (GDP) is characterised by the methodology of OECD as "the expenditure on final goods and services minus imports: final consumption expenditures, gross capital formation, and exports less imports: (OECD, 2016a, p.14; OECD, 2016). GDP in market prices is used in this research.

Another variable, international travel expenditures, "covers goods and services for own use or to give away acquired from other economies by residents during visits to these other economies" (OECD, 2016, p.14). In other words, these are the expenditures of international outbound visitors that are spent in other countries. Total travel expenditures could not be taken into consideration because these were not measured throughout the entire 7-year period in Norway, and thus the trends would be difficult to capture.

Secondary statistical data are in both countries stated in their own currency as exchange rate differences were not counted. While counting with GDP (see Figure 3), the USD currency was adapted to the Czech and Norwegian currencies in order to capture these relationships. 
These data were chosen because they traditionally highlight the economic situation regarding tourism and overall prosperity in the state and can serve as a starting point for examining the state's overall prosperity.

\section{Results and findings}

The economic importance of travel in both countries was conducted by a comparison of international travel expenditures and by looking at the trends for each country. It has confirmed that the importance of tourism in both countries has been growing. Firstly, the trends in international travel expenditures in the Czech Republic and in Norway were compared. The comparison revealed the following results; see Figure 1.

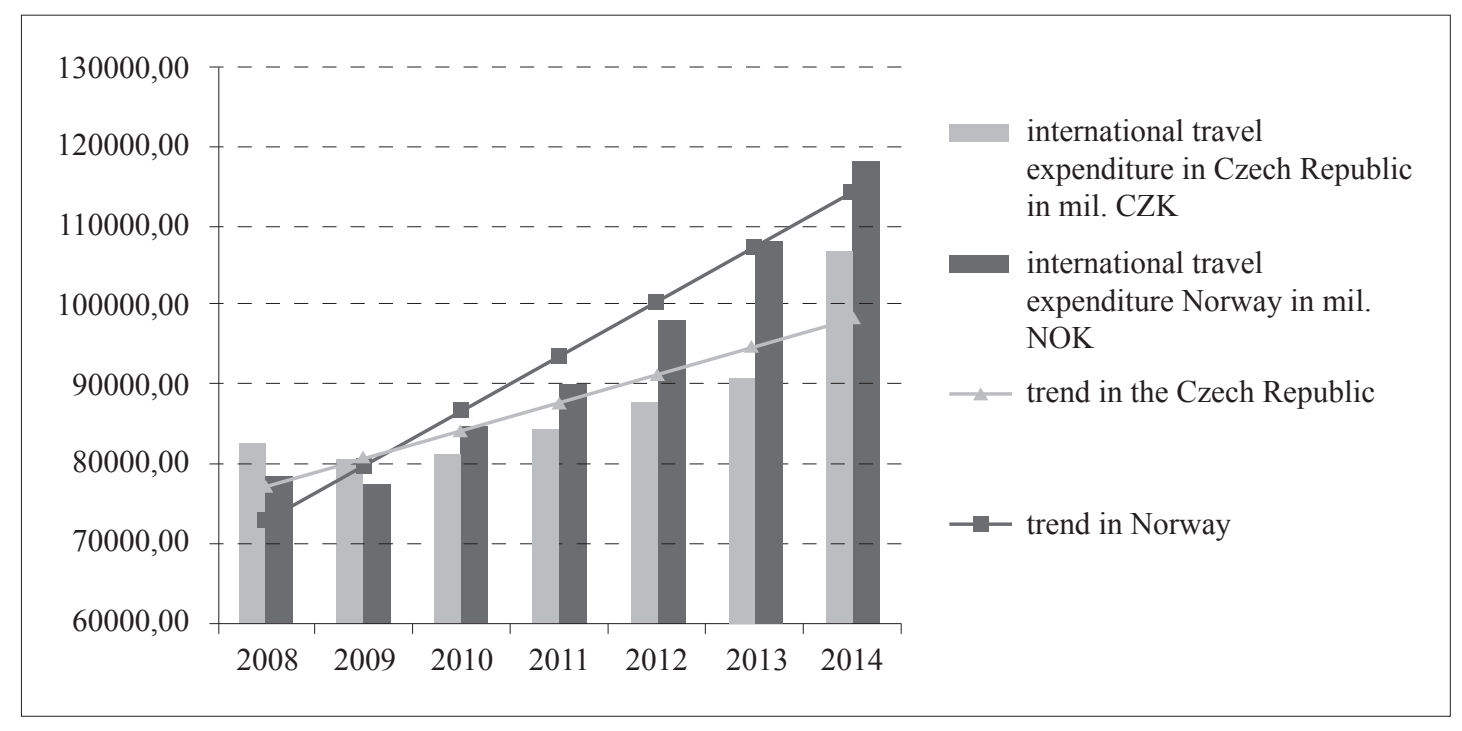

Fig. 1. Trends in international travel expenditures in Norway and in the Czech Republic

Source: (own processing based on OECD Stat., 2008-2014 and OECD, 2016a)

It is evident that the growth of international travel expenditures in Norway is quicker than in the Czech Republic, even though both of the countries exhibit a growing tendency. Although both countries demonstrate a positive trend, there is one point to note during the years of recession. The Czech Republic's recovery from recession period in question was slower and developed gradually, whereas in Norway the trend was quicker, which corresponds to previously-mentioned comments. Moreover, Norway was ranked as the state with the highest standard of living for its citizens based on the Human Development Index measured by United Nations (United Nations Development Programme, 2014). With this in mind, Norwegian tourists are used to high living standards, they travel more, require a higher standard of tourism services, and their overall approach differs based on their mentality. In addition to the previously mentioned behaviour of Norwegian tourists, the growth and expansion of international expenditures is therefore quicker compared to the Czech Republic

The previously mentioned recession during the economic crisis of 2008 and 2009 had an impact on changes in international arrivals when compared to other years. The following Figure 2 shows these changes compared to 2008. 


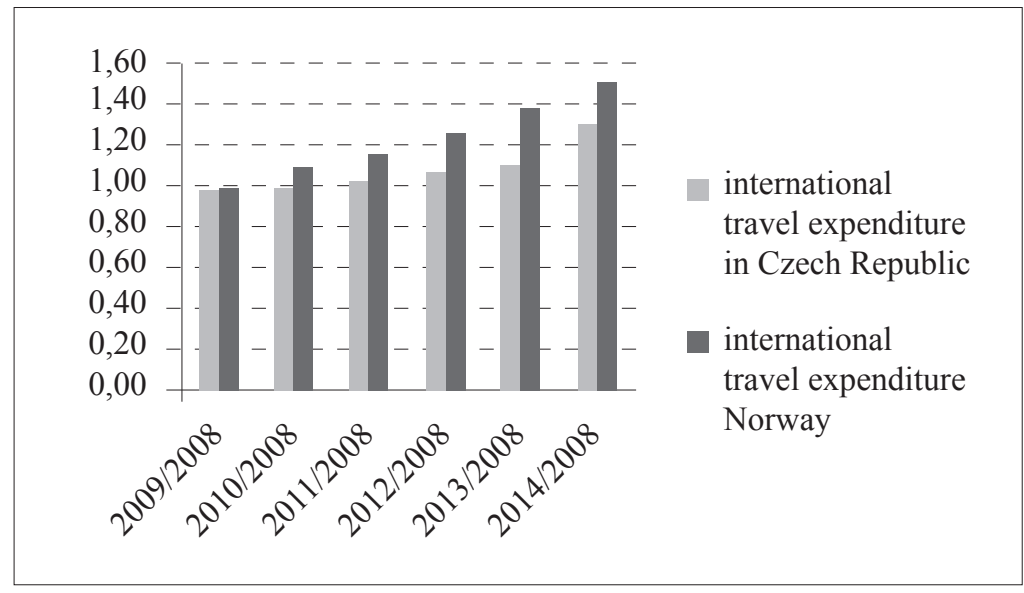

Fig 2. Changes in international travel expenditures for 2008 in Norway and the Czech Republic

Source: own processing based on OECD Stat., 2008-2014 and OECD, 2016a

The figure shows a gradual increase in international tourism expenditures in both countries; however, the trend behaves slightly differently for the Czech Republic. The recovery from the recession is most visible in 2013 and 2014 in the Czech Republic. Before then, expenditures remained stable and increased only slightly. This is not the case for Norway. The Norwegian recovery had already begun in 2009 and its notable increase is also seen in Figure 2. As proof, in Norway international travel expenditures have increased by $51 \%$ from 2008 , whereas in the Czech Republic this increase only amounted to $29 \%$. It can be expected that expenditures will grow with the capturing of similar economic conditions. Although for Czech tourists, their behaviour and attitudes are similar to those tourists from the Visegrad Four countries, there is still a room for taking inspiration from other developed tourism destinations.

When focusing on international travel expenditures and its deeper analysis, it can be seen that Norwegian and Czech tourism managers should pay more attention to monitoring economic cycles and the overall situation while examining the causalities. In order to see whether a deeper connection between national economy and international travel expenditures exists, Figure 3 describes the percentage of international travel expenditures from the overall GDP of Norway and the Czech Republic.

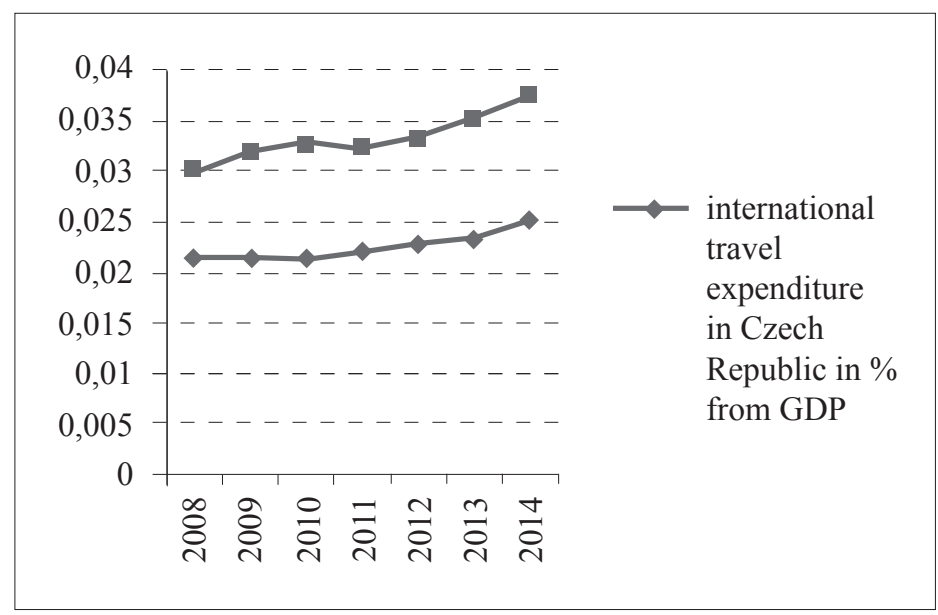

Fig. 3. International travel expenditures in \% of GDP for Norway and the Czech Republic Source: own processing based on OECD Stat., 2008-2014 and OECD, 2016a 
In Norway, there is then a rapid increase when comparing 2008 to 2014. This responds to the previously mentioned faster increase in expenditures. Based on this figure, it can be assumed that tourism in this case did not affect GDP because it follows a similar trend. The decrease is caused by industries other than tourism. On the contrary, the Czech Republic's percentage share of travel expenditures on GDP is stable in critical years, but it grows only slowly. This observation confirms the fact that favourable economic conditions at the end of 2013 and 2014 in the Czech Republic influenced tourist behaviour, encouraging them to spend more money for travelling abroad. This may be adapted for Norwegian tourists accordingly. Nowadays, a huge area has opened up to services involving various activities from earlier times as well as new opportunities for services that arise every day, which also can be applies to the field of tourism in both countries. (Tučková, Tuček, 2013)

\section{Conclusions}

This research was aimed at comparing two states with different approaches to tourism, Norway and the Czech Republic, in order to find out the similarities, differences, and connections with regard to overall gross domestic product and international travel expenditures. The research determined the following conclusions. Norway, as the country with the highest standard of living standard, has higher tourism expenditures for international journeys since tourists look for higher-quality services based on their mentality. Therefore, the curve of trend portrayed a sustained, more rapid upward trend than did the curve for the Czech Republic. The 2008 crisis hit both countries, causing decreases in expenditures as tourists were forced to limit their financial means and to prioritize their other basic needs before travel expenditures. Interestingly, the recovery from the crisis did not progress in a similar fashion. International travel expenditures began to increase more fully in 2013 and 2014 for the Czech Republic, while in Norway the recovery was already quicker in 2009. Therefore, this means that tourism managers and authorities should focus not only on classic economic data such as economic value added, return on equity, or other indicators, but that they should follow and predict the overall economic situation in the state and in the world, too. This is confirmed by the Figure 3, which described the percentage of international travel expenditures from overall GDP in each country. If GDP has is experience a tendency for growth, tourist expenditures for international journeys will adapt accordingly. The findings from the above-mentioned analysis are relevant for tourism managers and facilities because they can use the positive similarities between GDP and international travel expenditures for future sustainability measurements. One limit of this research resides in lacking same-source data in both countries for further comparison of additional tourism indicators in both states. Therefore, another limit can be seen in the non-objectivity of the research details, as it deals with only two variables. This leads us directly to the question or whether GDP would have an influence on other tourism indicators and whether these would also succumb to business cycles. Further research can support these findings by using other indicators and other methods such as correlation analysis to discover the causality.

\section{Acknowledgements}

The authors are thankful to the Internal Grant Agency of FaME TBU No. IGA/FaME/2017/017 (Economic sustainability in spa services) for financial support to carry out this research.

\section{References}

Akinboade, O., and L. Braimoh. 2009. International Tourism and Economic Development in South Africa: A Granger Causality Test. International Journal of Tourism Research 12 (2): 149-63. DOI: 10.1002/jtr.743 and Economic Growth: A Closer Look at Panels.” Tourism and Economic Growth: A Closer Look at Panels." Tourism

Balcilar, M., R. van Eyden; Inglesi-Lotz, R. 2014. Time-Varying Linkages between Tourism Receipts and Economic Growth in South Africa. Applied Economics 46 (36): 4381-98. DOI: http://dx.doi.org/10.1080/00036846.2014.957445

Bossel, H. 1999. Indicators for sustainable development: theory, method, applications. Winnipeg: International Institute for Sustainable Development.

Brockett, A.; Rezaee, Z. 2012. Corporate Sustainability: Integrating Performance and Reporting. New Jersey, USA: Willey, p. 336.

Cárdenas-García, P.; Sánchez-Rivero, M.; Pulido-Fernandéz, J. I. 2015. Does Tourism Growth Influence Economic Development? Journal of Travel Research 54 (2): 206 -221. DOI: 10.1177/0047287513514297 
Crouch, G. I. 1996. Demand elasticities in international marketing - a metaanalytical application to tourism. Journal of Business Research 36(2): 117-136. DOI: https://doi.org/10.1016/0148-2963(95)00086-0

Daly, H. 1996. Beyond Growth: The Economics of Sustainable Development. Boston: Beacon Press.

Dwyer, L.; Spurr, L. n.d. Tourism Economics Summary. STCRC Centre for Economics and Policy. Available on the Internet: $<$ http://www.t-stats-uk.co.uk/VTO/Documents/Stats\%20and\%20TSA/TourismEconomicsSummaryWEB.PDF>.

European Union. 2013. European Tourism Indicator System TOOLKIT for Sustainable Destinations. DG Enterprise and Industry.

Fleurbaey, M.; Blanchet, D. 2013. Beyond GDP: Measuring Welfare and Assessing Sustainability. New York: Oxford University Press.

Gallego et al. 2011. On the relationship between tourism and trade. In Cerina, F.; Markandya A.; McAleer, M. Economics of sustainable tourism. New York: Routledge. ISBN: 978-0-415-58385-5.

Gardetti M.A; Torres, A.L. 2016. Sustainability in Hospitality: How innovative hotels are transforming the industry. Shefield: Greenleaf Publishing Limited. ISBN-13: 978-1-78353-199-8.

Ghali, M.A. 1976. Tourism and Economic Growth: An Empirical Study. Economic Development and Cultural Change 24 (3): $527-538$. DOI: $10.1086 / 450895$

Gouveia, P. M.; Rodrigues, P. M. M. 2005. Dating and synchronizing tourism growth cycles. Tourism Economics 11(4): 501-515. DOI: $10.5367 / 000000005775108746$

Hall, M.; Gössling, S.; Scott, D. 2015. The Routledge Handbook of Tourism and Sustainability. New York: Routledge. ISBN: 978-0415-66248-2

Jurigová, Z. 2016. Tourism: New Destination of Global Business Environment. International Advances in Economic Research 22 (3): 351-352. DOI: $10.1007 / \mathrm{s} 11294-016-9584-\mathrm{x}$

Jurigová Z., Lencsésová Z. 2015. Monitoring System of Sustainable Development in Cultural and Mountain Tourism Destinations. Journal of Competitiveness, 7 (1), 35-52.

Lee, Chien C., and Chun P. Chang. (2008). “Tourism Development

Lee, Chien C., and Chun P. Chang. (2008). "Tourism Development

Lawn, P. 2006. Sustainable development indicators in ecological economics. Great Britain: MPG Books Ltd.

Lee, Chien C.; Chang, Ch.P. 2008. Tourism Development and Economic Growth: A Closer Look at Panels. Tourism Management 29 (1): 180-92. DOI: https://doi.org/10.1016/j.tourman.2007.02.013

Li, Ch.Ch.; Chuan O.S. 2012. Tourism receipts, education and economic growth in Malaysia. Current Issues in Hospitality and Tourism Research and Innovations - Zainal et al (eds). London: Taylor and Francis Group. ISBN 978-0-415-62133-5.

Moldan, B. 2003. (Ne)udržitelný rozvoj. Ekologie - hrozba i naděje. Praha: Karolinum.

Nováček, P. 2010. Indikátory udržitelného rozvoje. Available on the Internet: <http://www.futurologia.sk/pdf/novacek_udrzitelny_rozvoj_indikatory.pdf $>$.

OECD. 2016a. Gross domestic product (GDP). Available on the Internet: <https://data.oecd.org/gdp/gross-domestic-product-gdp.htm>.

OECD. 2016b. OECD Tourism Trends and Policies 2016. Paris: OECD Publishing. DOI: http://dx.doi.org/10.1787/tour-2016-en

OECD Stat. 2008-2014. Receipts and expenditure. Available on the Internet: $<$ http://stats.oecd.org/index.aspx?DataSetCode=TOURISM REC_EXP>.

Oyola, M.; Blancas, J. F.; González, M.; Caballero, R. 2012. Sustainable tourism indicators as planning tools in cultural destinations. Spain: Malaga University. Ecological Indicators 18: 659-675. DOI: http://dx.doi.org/10.1016/j.ecolind.2012.01.014

Ridderstaat, J.; Croes, R.; Nijkamp, P. 2014. Tourism and Long-Run Economic Growth in Aruba. International Journal of Tourism Research 16 (5): 472-87. DOI: 10.1002/jtr.1941

Rio, D.; Nunes, L. M. 2012. Monitoring and evaluation tools for tourism destinations. Tourism Management Perspectives 4: 64-66. DOI: http://dx.doi.org/10.1016/j.tmp.2012.04.002 
Song, H.; Li, G. 2008. Tourism demand modelling and forecasting - A review of Recent research. Tourism Management 29 (2): $203-220$. DOI: $10.1016 /$ j.tourman.2007.07.016

Tučková, Z.; Tuček, D. 2013. Economic evaluation of the level of knowledge services in selected OECD countries. Proceedings of the European Conference on Knowledge Management, ECKM , 2, pp. 732-740

United Nations Development Programme. 2012. Going beyond GDP, UNDP proposes human development measure of sustainability. Available on the Internet: <http://www.undp.org/content/undp/en/home/presscenter/pressreleases/2012/06/20/oing-beyond-gdp-undpproposes-human-development-measure-of-sustainability.html>.

United Nations Development Programme. 2014. Human Development Index and its components. Available on the Internet: $<$ http://hdr. undp.org/en/composite/HDI>.

UNWTO. 2015. International tourist arrivals up 4\% driven by strong results in Europe. Press release no. 15079. Spain: Madrid. Available on the Internet: $<$ http://media.unwto.org/press-release/2015-10-29/international-tourist-arrivals-4-driven-strong-results-europe> .

Vojnovic, N.; Knezevic, R. 2013. Economic and tourism indicators as a means of monitoring sustainable tourist: The case of inland Istria. UTMS Journal of Economics 4 (2): 213-230.

World Tourism Organization. 2004. Indicators of Sustainable Development for Tourism Destinations: A Guidebook. Spain: World Tourism Organization.

WTTC. 2015a. Travel and Tourism: Economic Impact 2015. Czech Republic. Available on the Internet: <https://www.wttc.org/-/media/ files/reports/economic\%20impact\%20research/countries\%202015/czechrepublic2015.pdf>.

WTTC. 2015b. Travel and Tourism: Economic Impact 2015. Norway. Available on the Internet: $<$ https://www.wttc.org/-/media/files/ reports/economic\%20impact\%20research/countries\%202015/norway2015.pdf>.

\section{Biographical note about the contributors}

Zuzana JURIGOVÁ is a PhD. student and assistant at Tomas Bata University in Zlín. She gained her master's degree at the Faculty of Management and Economics of Tomas Bata University in Zlín in the field of Business Economics with Specialization on Tourism. Throughout her research and academic career, she deals with economics of services, tourism sustainability, concretly economic sustainability in hotels and business economics. She is a co-solver of several projects such as Visegrad Grant aimed at tourism, Norwegian grant aimed at social entrepreneurship or Internal Grant Agency aimed at economic sustainability in tourism.

Zuzana TUČKOVÁ worked at the Faculty of Management and Economics of Tomas Bata University in Zlin from 2006 at the Department of Business Economics. Currently she works as a vice-dean at the Faculty Logistics and Crisis Management. In 2013 she was habilitated. Within her research she deals with the research in the area of business economics with specialization on tourism, social entrepreneurship and economics of services. She has rich experience with international project management. Under her guidance these projects were successfully finished with practical scientific results e.g. project grant Visegrad University Studies Gran, no. 60900009, solver of the grant Visegrad Standard Grant no. 21220002, project title: The Meaning of Tourism and Tourism Services in the V4 countries and co-solver of Visegrad Standard Grant no. 21220297 and two Norwegian grants entitled "The creation and support of the research team in the logistics industry as the base for bilateral cooperation" and "Building a research team in the field of social economy as sources of sustainable economic growth of post-industrial European regions".

Oskar SOLENES is Associated Professor in Sport Management and Dean at the Faculty of Business Administration and Social Sciences at Molde UniversityCollege, Norway. Previously he served as the Head ofStudy Program in Sport Management and Event Management, and has experience in developing study programs within the field. Oskar holds a PhD from the Norwegian School of Sport Studies from 2009 focusing on the development of organized sport for children in Norway during the $20^{\text {th }}$ century. His research interests are especially in sport history and the organizing of children's and youth sport in Norway - a topic on which he has published articles in Norwegian books and journals. He has also conducted research on voluntarism in sport, as well as on the social, cultural and economic value of a top tier football club to its local community. He has published articles in Sport in Society and European Journal for Sport and Society.

This is an open access journal and all published articles are licensed under a Creative Commons Attribution 4.0 International License 